Denson, K. W. E. (1968). Two forms of haemophilia ? (Letter). Lancet, 2, 222-223.

Denson, K. W. E., Biggs, R., Haddon, M. E., Borrett, R., and Cobb, K. (1969). Two types of haemophilia $\left(A^{+}\right.$and $\left.A^{-}\right)$. A study of 48 cases. Brit. J. Haemat., 17, 163-171.

Feinstein, D., Chong, M. N. Y., Kasper, C. K., and Rapaport, S. I. (1969). Hemophilia A: polymorphism detectable by a factor VIII antibody. Science, 163, 1071-1072.

Hoyer, L. W., and Breckenridge, R. T. (1968). Immunologic studies of antihaemophilic factor (AHF, Factor VIII): Cross-reacting material in a genetic variant of hemophilia A. Blood, 32, 962-971.

Meyer, D., Dray, L., and Larrieu, M. J. (1970). Hemophilie. Les variants des facteurs VIII et IX. Nouv. Rev. frans. Hémat., 10, 619-629.

Pitney, W. R. (1956). The assay of antihaemophilic globulin (AHG) in plasma. Brit.J. Haemat., 2, 250-264.

\section{Lysing Agent for the Coulter S}

I was interested in a recent letter (Nicol, D. J., and Davis, R. E., 1971, J. clin. Path., 24, 882) which describes reagents for use with the Coulter counter model S. An alternative lysing agent which has been in routine use in this laboratory since February 1971 is a $2 \%$ solution of Ethyl hexadecyl dimethyl ammonium bromide (Tech) ${ }^{1}$ in Isoton ${ }^{2}$. The cost of preparation of a diluent similar in quality to Isoton appeared to be prohibitive but use of this substitute lysing agent has allowed an economy in this laboratory in excess of f1 000 per annum. The solution is particle free and has a shelf life in excess of one year. White blood cell counts and haemoglobin estimates comparing Lyse $\mathbf{S}^{2}$ and this lysing agent show no significant differences. The absorption spectra of haemoglobin solutions prepared with this reagent are very similar to those obtained at $546 \mathrm{~nm}$ with Lyse $\mathrm{S}$ (maximum differences were $\pm 2 \%$ absorbance).

We prepare the reagent for use by adding $400 \mathrm{~g}$ of chemical to 20 litres of Isoton.

B. C. D. BALLARD Department of Pathology, The Gibson Laboratories, Radcliffe Infirmary, Oxford

${ }^{1}$ Kodak Ltd, catalogue no. T. 5661

${ }^{2}$ Coulter Electronics, Dunstable, Beds

\section{Book reviews}

Transplantation Today Edited by Hans Balner, D. W. van Bekkum, and Felix T. Rapaport. (Pp. xxiv + 978. \$25.00.) New York and London: Grune and Stratton Inc. 1971.

The Third International Congress of the Transplantation Society was held in September 1970. The proceedings were published six months later as Volume 3, No. 1 of Transplantation Proceedings, and priced at $\$ 20$. The volume reviewed here is the same material put between hard covers, provided with a title, and somewhat more expensively priced.

It consists of some 240 papers, mainly of three to four pages each, covering most (but by no means all) of the vast field of clinical and experimental transplantation of interest today. The largest section (about 200 pages) deals with transplantation antigens in man and other species, including their genetics and chemistry. Other topics covered include clinical transplantation (selection of donor, special problems in transplantation of kidney, liver, lung, bone marrow, pancreas and heart, etc.), antilymphocyte serum, tolerance and enhancement, microsurgical techniques, tissue and organ preservation, and cross-species transplantation. Papers that do not fit readily into other sections are collected under 'Fundamental transplantation immunology'.

As these papers were for presentation at a scientific congress, they tend to be rather specialized, and they will be of most interest to clinical or experimental workers in the transplantation field.

It is unfortunate that several diagrams have been compressed within a half-page width. Some of these are literally unreadable without a magnifying glass.

M. C. BERENBAUM

Clinical Chemical Pathology 6th edn By C. H. Gray. (Pp. $x+244$; illustrated. £2.00.) London: Edward Arnold (Publishers) Ltd. 1971.

This book forms the basis of instruction in chemical pathology to the clinical medical students at Kings College Hospital, London. There is one new chapter in this edition and three chapters have been re-written but the book has been maintained at the same length as the previous edition by effective pruning of material.

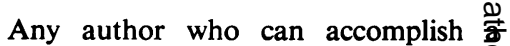
reasonably full and lucidly written des? cription of chemical pathology in less tha 250 pages is to be congratulated. Professof Gray deserves our congratulations.

The reviewer found the chapter on acio base confusing. A more general approacti to biochemical genetics rather than listing of known conditions would hav been more interesting. The rewritten chapters on renal function and hormones are excellent summaries.

The publishers are to be congratulate $\overrightarrow{\mathbb{g}}$ on the price of $£ 2$.

T. P. WHITEHEA

Practical Section Cutting and Staining $5 \mathrm{t}$ 院 edn By E. C. Clayden, (Pp. 270; illustrated. £3.00.) Edinburgh and Londonos Churchill Livingstone. 1971.

Successfully retaining the "little book? image, Mr Clayden has produced a fifth

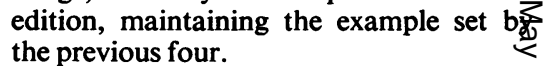

This humble book has probably aide and advised more than would care to admit, and given encouragement to many students contemplating a career if technical histology.

Cleverly brought up to date withoư⿱ pretending to be comprehensive, th\& volume includes little that is superfluou and is still the best 'starter' for students I. HUNTER

Ask the Lab-the Career of a Medica Laboratory Technician By Kenneth. Hughes. (Pp. 125; illustrated. £1.50 Reading: Educational Explorers. 1971.

Many medical laboratory technicians wiff. recognize the need for a book of this kin $\Phi$ -certainly they will recognize their ow laboratories. But, in emphasizing the vocational and humanitarian aspects of this career, the author has sometimes obscured its essential scientific nature.

There is, perhaps, insufficient mentiof of those dynamic changes taking place, now in hospital laboratories, both ip technical development and in training ot personnel, to highlight the challenge the might present to inquisitive young schoed leavers.

CELIA NELSORP 